\title{
PRE UNDERSTANDING, EFFECTIVE HISTORI, FUSION OF \\ HORISONS KOMISI PENYIARAN INDONESIA DAERAH (KPID NTB) \\ TERHADAP UNDANG-UNDANG PENYIARAN NO 32 TAHUN 2002 \\ DAN P3SPS
}

\author{
NAJAMUDIN \\ Dosen Universitas Islam Negeri Mataram \\ Email: najamudin@uinmataram.ac.id
}

\begin{abstract}
Abstrak
Pre Understanding, Effective Histori, Fusion of Horisons istilah hermeneutik sebagai dasar untuk memahami. Sedangkan KPID adalah lembaga yang otoritatif pada pengawasan penyiran di daerah yang mengacu pada UU Penyiaran 32 Tahun 2002. Hadirnya lembaga penyiaran di NTB memiliki dampak positive negative, yaitu mampu memenuhi kebutuhan informasi bagi masyrakat NTB, tapi juga menambah permasalahan, seperti perilaku kekerasan oleh anak-anak, Pelecehan seksual oleh anak-anak maupun dewasa, kata-kata kotor oleh anak-anak dan lainnya. Prilaku tersebut diilustrasikan melalui Televisi. Pada tahap implementasi kebijakan dan pemahaman KPID tentang UU Penyiaran dan P3SPS peneliti melihatnya menggunakan teori hermneutika Gadamer dan Ripley "pendekatan kepatuhan dalam impelentasi kebijakan”. Terjadinya ketidakpatuhan tersebut disebabkan oleh kebijakan tersebut hanya berlaku formalitas, atau dalam logika hermeneutika apa yang KPID lakukan baru sebatas pemahaman literal, sehingga perlu diuji dengan Pre Understanding, Effective Histori, Fusion Of Horisons.
\end{abstract}

Kata Kunci: Pre Understanding, Effective Histori, Fusion of Horisons, UU Penyiaran, P3SPS, KPID, Lembaga, Penyiaran

\section{Pendahuluan}

Perkembangan lembaga penyiaran terkini di Provinsi NTB bisa dibilang cukup pesat. Saat ini bedasarkan data dari KPID Provnsi NTB, jumlah lembaga penyiaran yang ada di Kota Mataram dan umumnya di NTB sebagai mana yang tertera pada table berikut: 


\begin{tabular}{|c|c|c|c|c|}
\hline No & Stasiun Televisi & Frekuensi & Jaringan & Kabupaten / Kota \\
\hline 1 & TVRI Nusa Tenggara Barat & UHF & TVRI & Mataram \\
\hline 2 & Lombok TV & 22 UHF & City TV Network & Mataram \\
\hline 3 & iNews TV Mataram & 38 UHF & iNews TV & Mataram \\
\hline 4 & Sasambo TV & 42 UHF & STTV & Mataram \\
\hline 5 & Lombok Post TV & 44 UHF & Jawa Pos TV & Mataram \\
\hline 6 & NET. Mataram & 58 UHF & NET. & Lombok Barat \\
\hline 7 & TV9 Lombok & 60 UHF & & Tama \\
\hline 8 & Bima TV & 51 UHF & TempoTV & \\
\hline 9 & TV Sumbawa Barat & & & \\
\hline
\end{tabular}

Eksistensi lembaga-lembaga penyiaran yang ada di NTB, dalam perkembangannya tentu saja tidak hanya memenuhi kebutuhan akan informasi bagi masyrakat NTB, akan tetapi pada sisi atau aspek lainnya juga menambah berbagai macam masalah, pertumbuhan dan perkembangan stasiun televisi sebagai industri penyiaran adalah suatu kenyataan bersinggungan langsung dengan dunia bisnis. Persaingan di antara media penyiaran televisi merupakan akibat derivatif yang tak mungkin dihindari. ${ }^{1}$ Menurut pengamatan penelitian, terjadi persaingan di antara para praktisi penyiaran dalam dunia bisnis. Kerja sama antara pebisnis kapitalis dengan media penyiaran merupakan suatu keniscayaan, produduser membuat program-program terbaik sesuai keinginan penonton. Bagi stasiun televisi swasta, program adalah napas kehidupan televisi. Melalui program pula penonton dihibur dan dipenuhi kebutuhannya. Dalam penayangan program tersebut, pihak ketiga diikutsertakan memasang iklan di stasiun televisi. Indikasi keberhasilan sebuah program ditandai dengan jumlah penonton yang banyak, dan memudahkan mendapatkan iklan, yang menjadi sumber pemasukan utama bagi stasiun televisi swasta. ${ }^{2}$

Gambaran-gambaran tersebut mendeskripsikan dua kepentingan sekaligus. Industri pertelevisian tidak dapat melepaskan diri dari kepentingan pemodal kapitalis, yang berusaha mendapatkan keuntungan sebesar-besarnya. Pada sisi lain nilai-nilai edukasi yang seharusnya dimuat selama tayangan program diabaikan. Contoh salah satu program yang sering melakukan pelanggaran terhadap regulasi penyiaran adalah program ”Wayang Lalu Nasib, Sasak Tulen, yang ditayangkan oleh Lombok TV hingga saat ini, Presean yang ditayangkan oleh TV9 dan lain-lain. Menurut catatan dan laporan masyarakat yang masuk ke KPID program-program yang ditayangkan oleh beberapa TV tersebut menyalahi Undang-Undang

1 . Febri Eko Prasetyo, Peranan Komunikasi Dalam Mengoptimalkan Komisi Penyiaran Indonesia Daerah (KPID) Kalimantan Timur Dalam Melakukan Pengawasan Lembaga Penyiaran di Samarinda e-Jurnal Ilmu Komunikasi, 2015 FISIP-UNMUL

2. Data hasil observasi awal peneliti ketika melakukan pengamatan secara langsung maupun secara tidak langsung terhadap beberapa Lembaga Penyiaran di Kota Mataram, seperti Lombok TV, TV9 dan KPID Provinsi NTB 
Penyiaran No 32 Tahun 2002 dan Pedoman Perilaku Penyiran dan Standar Siaran (P3SPS), karena menayangkan vidio dengan menggunakan bahasa kasar, vidio erotis, dan adegan kekerasan fisik ${ }^{3}$.

Penayangan program siaran tersebut secara tidak langsung menyalahi kode etik penyiaran TV jika mengacu kepada Undang-Undang Penyiaran, karena beberapa program tersebut mengandung unsur pornografi, bahasa yang kasar dan adegan kekerasan. Dalam hal ini KPID NTB sebagai lembaga idependen yang bertugas melakukan pengawasan tersebut terkesan melakukan upaya pembiaran, hal ini dapat dibuktikan dengan masih ditayangkannya program-program tesebut pada dua lembaga penyiaran yang telah disebutkan sebelumnya. Berangkat dari adanya fenomena penayangan program penyiaran TV tersebut, maka hal ini menarik untuk diketahui tentang bagaimana Pre Understanding, Effective Histori, Fusion of Horisons Dalam Hermeneutika Gaddamer, Komisi Penyiaran Indonesia Daerah Terhadap Undang-Undang Penyiran No 32 Tahun 2002 dan (P3SPS) Terhadap Fenomena Penayangan Program Siaran di NTB. ${ }^{4}$

\section{A. Konsep Pre Understanding, Effective Histori, Fusion of Horisons Dalam Hermeneutika Gaddamer.}

Karya Gadamer yang cukup popular adalah truth and method. Gadamer banyak menginspirasi dan diidolakan oleh banyak kalangan ilmuan termasuk oleh Fazlurrahman.

Pengaruhnya Hieddeger terhadap pemikiran Gadamer sebanyak separuh dari pemikiran Heiddeger, termasuk beberapa teori yang dilahirkan oleh Gaddamer Pre Understanding, Effectiv Historis, Fusion Of Horisons dan Aplikasi. Berikut di bawah ini beberapa teori Gaddamer menurut pemahaman penulis:

1. Adanya Pre Understanding. Ketika orang memahami, maka pada hakikatnya bukan dari tidak tau menjadi tau, tetapi dari pemahaman yang lama menjadi pemahaman yang baru, kenapa demikian, karena di kepala manusia pastinya sudah ada apa yang disebut dengan Pre-Understanding dari pemahaman. Dikepala manusia sudah ada pemahaman awal, konsep awal, teori awal dalam memahami. karena itu menurut Gadamer Hermeneutika bukan hanya sekedar seni (filologi/ seperti yang

\footnotetext{
3 . Komisi Penyiaran Indonesia, Pedoman Perilaku Penyiaran (P3) Dan Standar Program Siaran (SPS), (Jakarta: Komisi Penyiaran Indonesia Pusat, 2012), hlm, 55

4. Astrid Sunario, Komunikasi Pengendalian dan Komunikasi Pengawasan (Jakarta : Pustaka Sinar Harapan,1989), hlm. 21
} 
disampaikan oleh Schleirmacher) atau metode (Dilthey), namun ontology (hakikat hidup kita sebagai manusia).

Selama masih menjadi manusia normal pasti ada Pra-Pemahaman, selama masih bisa mikir pasti terlibat Pra-Pemahaman, ketika pikiran itu mandeg, maka pasti saat itu juga kita tidak pake Pra-Pemahaman, atau kita tidak bisa mikir tentang apa saja. Dari beberapa penjelasan tersebut kemudian Gadamer memunculkan sebuah teori yang cukup phenomenal yang disebut dengan Effective History (Sejarah Pengaruh).

2. Effective History (Sejarah Pengaruh)

Selalu ada "sejarah pengaruh" yang berkerja dalam aktifitas memahami, meskipun jarang disebut. Secara umum "sejarah pengaruh” dapat dikatakan sebagai proses sebuah karya mempengaruhi karya yang lain. Demi “obyektifitas” dalam memahami "sejarah pengaruh" ini harus disadari. Lapisan kesadaran akan "sejarah pengaruh meliputi hal-hal sebagai berikut:

a. Kesadaran akan "ketersitasian” orang yang memahami

b. Keasadaran akan pengaruh tradisi dalam setiap pemahaman

c. Kesadaran sebagai anak zaman

d. Refleksi diri atas "sejarah pengaruh"

3. Fusion of Horisons (Peleburan Atar Horison)

Horison dapat diartikan sebagai perspektif, pengetahuan atau kesadaran. Fusion of Horisons berarti meleburnya Horison yang memahami dengan yang dipahami dan melahirkan horison yang baru. Peleburan ini pada ahirnya akan menjadikan horison yang dimiliki oleh seorang pemaham akan semakin luas. Misalnya bagaimana kita membaca buku komik waktu kita kecil dulu dengan saat dewasa sekarang akan sangat berbeda karena horison kita semakin luas. Oleh karena itu interpretasi yang berhasil itu coraknya bukan Reproduksi Makna lama namun Produksi Makna karena hasil interperetasi selalu horison-horison yang baru. ${ }^{5}$

\section{Pre Understanding, KPID NTB Terhadap Undang-Undang Penyiaran No. 32 Tahun 2002 Dan P3SPS Dalam Melakukan Pengawasan Siaran.}

Menurut Gadamer, apapun yang dikembangkan dalam konteks pemikiran termasuk hukum tidak muncul dengan sendirinya, tetapi selalu mengacu pada konsep lama yang telah dikembangkan oleh generasi sebelumnya. Konsep pengembangan tersebut kemudian

5 . Hans Georg Gadamer, Truth and Method Hans Georg Gadamer, translations revised by Joel Weinsheimer and Donald G Marshal (Newyork: Continuum Publishing Group, 2004), hlm. 11-23 
disebut dengan tradisi dan otoritas. Dua istilah tersebut kemudian dijadikan sebagai pijakan awal untuk melakukan pengembangan berikutnya, termasuk dalam pengembangan dalam proses memahami hokum, terutama dalam konteks pemahaman KPID terhadap UU No 32 dan P3SPS tentang penyiaran.

Eksistensi KPI adalah bagian dari wujud peran serta masyarakat dalam hal penyiaran, baik sebagai wadah aspirasi maupun mewakili kepentingan masyarakat (UU Penyiaran, pasal 8 ayat 1). Legitimasi politik bagi posisi KPI dalam kehidupan kenegaraan berikutnya secara tegas diatur oleh UU Penyiaran sebagai lembaga negara independen yang mengatur hal-hal mengenai penyiaran (UU Penyiaran, pasal 7 ayat 2). Secara konseptual posisi ini mendudukkan KPI sebagai lembaga kuasa negara atau dalam istilah lain juga biasa dikenal dengan auxilarry state institution.

URAIAN TUGAS DAN KEWENANGAN KPI

BERDASARKAN UU PENYIARAN, PEDOMAN PERILAKU PENYIARAN (P3), DAN STANDAR PROGRAM SIARAN (SPS)

BERDASARKAN UU NO. 32 TAHUN 2002 TENTANG PENYIARAN

EKSISTENSI KPI

TUGAS DAN KEWENANGAN KPI

Pasal 8

1. KPI sebagai wujud peran serta masyarakat berfungsi mewadahi aspirasi serta mewakili kepentingan masyarakat akan penyiaran.

2. Dalam menjalankan fungsinya sebagaimana dimaksud dalam ayat (1), KPI mempunyai wewenang:

a. menetapkan standar program siaran;

b. menyusun peraturan dan menetapkan pedoman perilaku penyiaran;

c. mengawasi pelaksanaan peraturan dan pedoman perilaku penyiaran serta standar program siaran;

d. memberikan sanksi terhadap pelanggaran peraturan dan pedoman perilaku penyiaran serta standar program siaran;

e. melakukan koordinasi dan/atau kerjasama dengan Pemerintah, lembaga penyiaran, dan masyarakat.

3. KPI mempunyai tugas dan kewajiban :

a. menjamin masyarakat untuk memperoleh informasi yang layak dan benar sesuai dengan hak asasi manusia;

b. ikut membantu pengaturan infrastruktur bidang penyiaran;

c. ikut membangun iklim persaingan yang sehat antarlembaga penyiaran dan industri terkait;

d. memelihara tatanan informasi nasional yang adil, merata, dan seimbang;

e. menampung, meneliti, dan menindaklanjuti aduan, sanggahan, serta kritik dan apresiasi masyarakat terhadap penyelenggaraan penyiaran; dan

f. menyusun perencanaan pengembangan sumber daya manusia yang menjamin profesionalitas di bidang penyiaran.

\section{TUGAS DAN KEWENANGAN KPI TERKAIT PEDOMAN PERILAKU PENYIARAN}

Pasal 48

1. Pedoman perilaku penyiaran bagi penyelenggaraan siaran ditetapkan oleh KPI.

2. Pedoman perilaku penyiaran sebagaimana dimaksud dalam ayat (1) disusun dan bersumber pada:

a. nilai-nilai agama, moral dan peraturan perundang-undangan yang berlaku; dan

b. norma-norma lain yang berlaku dan diterima oleh masyarakat umum dan lembaga penyiaran.

3. KPI wajib menerbitkan dan mensosialisasikan pedoman perilaku penyiaran kepada Lembaga Penyiaran dan masyarakat umum.

4. Pedoman perilaku penyiaran menentukan standar isi siaran yang sekurang-kurangnya berkaitan dengan:

a. rasa hormat terhadap pandangan keagamaan; 


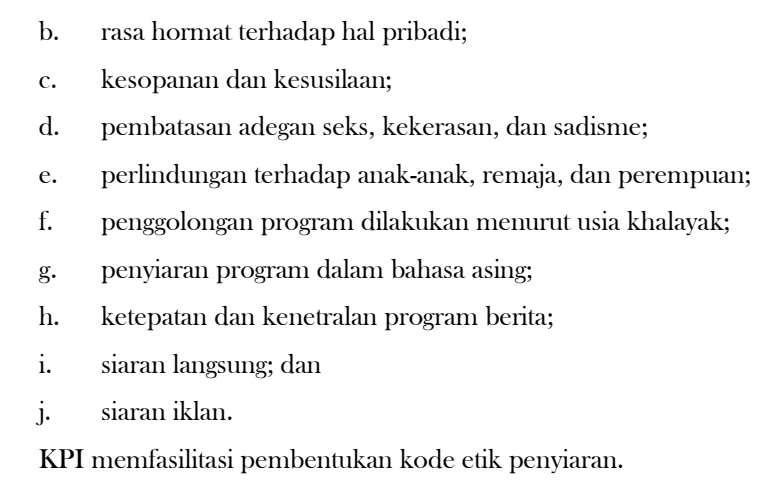

$$
\text { Pasal } 50
$$

1. KPI wajib mengawasi pelaksanaan pedoman perilaku penyiaran.

2. KPI wajib menerima aduan dari setiap orang atau kelompok yang mengetahui adanya pelanggaran terhadap pedoman perilaku penyiaran.

3. KPI wajib menindaklanjuti aduan resmi mengenai hal-hal yang bersifat mendasar sebagaimana dimaksud dalam Pasal 8 ayat (3) huruf e.

4. KPI wajib meneruskan aduan kepada lembaga penyiaran yang bersangkutan dan memberikan kesempatan hak jawab.

5. KPI wajib menyampaikan secara tertulis hasil evaluasi dan penilaian kepada pihak yang mengajukan aduan dan Lembaga Penyiaran yang terkait.

$$
\text { Pasal } 51
$$

1. KPI dapat mewajibkan Lembaga Penyiaran untuk menyiarkan dan/atau menerbitkan pernyataan yang berkaitan dengan aduan sebagaimana dimaksud dalam Pasal 50 ayat (2) apabila terbukti benar.

2. Semua Lembaga Penyiaran wajib menaati keputusan yang dikeluarkan oleh KPI yang berdasarkan pedoman perilaku penyiaran.

\section{PERTANGGUNGJAWABAN KPI}

$$
\text { Pasal } 53
$$

1. KPI Pusat dalam menjalankan fungsi, wewenang, tugas, dan kewajibannya bertanggung jawab kepada Presiden dan menyampaikan laporan kepada Dewan Perwakilan Rakyat Republik Indonesia.

2. KPI Daerah dalam menjalankan fungsi, wewenang, tugas, dan kewajibannya bertanggung jawab kepada Gubernur dan menyampaikan laporan kepada Dewan Perwakilan Rakyat Daerah Provinsi.

\section{SANKSI-SANKSI YANG DAPAT DIJATUHKAN OLEH KPI}

Sanksi administratif sebagaimana dimaksud dalam ayat (1) dapat berupa :

a. teguran tertulis;

b. penghentian sementara mata acara yang bermasalah setelah melalui tahap tertentu;

c. pembatasan durasi dan waktu siaran;

d. denda administratif;

e. pembekuan kegiatan siaran untuk waktu tertentu;

f. tidak diberi perpanjangan izin penyelenggaraan penyiaran;

g. pencabutan izin penyelenggaraan penyiaran.

\section{BERDASARKAN PERATURAN KOMISI PENYIARAN INDOENSIA NOMOR 2 TAHUN 2007 TENTANG PEDOMAN} PERILAKU PENYIARAN

\section{PENGAWASAN KPI TERHADAP PEDOMAN PERILAKU PENYIARAN}

$$
\text { Pasal } 17
$$

1. KPI mengawasi pelaksanaan Pedoman Perilaku Penyiaran.

2. Pedoman Perilaku Penyiaran harus menjadi pedoman lembaga penyiaran dalam memproduksi suatu program siaran.

3. Pedoman Perilaku Penyiaran wajib dipatuhi oleh semua lembaga penyiaran 


\section{KEWENANGAN KPI TERKAIT DENGAN PENGADUAN TERHADAP ADANYA PELANGGARAN PEDOMAN PERILAKU PENYIARAN \\ Pasal 19}

Setiap orang atau sekelompok orang yang mengetahui adanya pelanggaran terhadap Pedoman Perilaku dapat mengadukan ke KPI. Pasal 20

KPI menampung, meneliti, dan menindaklanjuti aduan, sanggahan, serta kritik dan apresiasi masyarakat terhadap penyelenggaraan penyiaran.

$$
\text { Pasal } 21
$$

Dalam hal KPI memutuskan untuk mempertimbangkan keluhan dan atau pengaduan, Lembaga Penyiaran tersebut diundang untuk didengar keterangannya guna mendapatkan klarifikasi dan penjelasan lebih lanjut tentang materi program yang diadukan tersebut.

$$
\begin{gathered}
\text { Hak Jawab } \\
\text { Pasal } 22
\end{gathered}
$$

1. KPI memberikan kesempatan kepada Lembaga Penyiaran yang diduga melakukan pelanggaran atas Pedoman Perilaku Penyiaran untuk melakukan klarifikasi berupa hak jawab, baik dalam bentuk tertulis maupun dalam bentuk didengar langsung keterangannya sebelum keputusan ditetapkan.

2. Berkaitan dengan ketentuan ayat (1) di atas, setiap Lembaga Penyiaran harus menunjuk seorang 'penangan pengaduan' yang akan menangani setiap laporan dan pengaduan tentang kemungkinan pelanggaran.

\section{Pencatatan Pelanggaran}

$$
\text { Pasal } 25
$$

Setiap pelanggaran yang dilakukan oleh Lembaga Penyiaran terhadap Pedoman Program Penyiaran akan dicatat dan direkam oleh KPI dan akan menjadi bahan pertimbangan bagi KPI dalam hal memberikan keputusan-keputusan yang menyangkut Lembaga Penyiaran, termasuk keputusan dalam hal perpanjangan izin siaran.

\section{KEWENANGAN KPI TERKAIT MATERI REKAMAN SIARAN DAN KEPUTUSAN}

$$
\text { Pasal } 23
$$

1. Untuk kepentingan pengambilan keputusan, KPI memiliki wewenang untuk meminta kepada lembaga penyiaran yang bersangkutan untuk memperlihatkan rekaman bahan siaran yang diadukan lengkap dengan penjelasan-penjelasan tertulis dari penanggung jawab program lembaga penyiaran tersebut.

2. Berkaitan dengan ayat (1), lembaga penyiaran wajib menyimpan materi rekaman siaran selama minimal satu tahun.

BERDASARKAN PERATURAN KOMISI PENYIARAN INDONESIA NOMOR 3 TAHUN 2007 TENTANG STANDAR PROGRAM SIARAN

\section{Pengawasan}

Pasal 67

1. KPI mengawasi pelaksanaan Standar Program Siaran.

2. Standar Program Siaran wajib dipatuhi oleh semua lembaga penyiaran.

3. Lembaga penyiaran wajib memperhatikan Standar Program Siaran dalam proses pengolahan, pembuatan, pembelian, penayangan, penyiaran dan pendanaan program siaran lembaga penyiaran bersangkutan, baik lokal mau pun asing.

\section{HAK JAWAB LEMBAGA PENYIARAN KEPADA KPI}

$$
\text { Pasal } 72
$$

1. KPI memberikan kesempatan kepada Lembaga Penyiaran yang diduga melakukan pelanggaran atas Standar Program Siaran tersebut untuk melakukan klarifikasi berupa hak jawab, baik dalam bentuk tertulis maupun dalam bentuk didengar langsung keterangannya sebelum keputusan ditetapkan.

$$
\text { Pasal } 73
$$

1. Untuk kepentingan pengambilan keputusan, KPI memiliki wewenang untuk meminta kepada lembaga penyiaran yang bersangkutan, untuk memperlihatkan rekaman bahan siaran yang diadukan, lengkap dengan penjelasan-penjelasan tertulis dari penanggung jawab program lembaga penyiaran tersebut. 
2. Berkaitan dengan ayat (1), lembaga penyiaran wajib menyimpan materi rekaman siaran selama minimal satu tahun.

$$
\text { Pasal } 75
$$

1. Setiap pelanggaran yang terbukti dilakukan oleh lembaga penyiaran akan tercatat secara administratif dan akan mempengaruhi keputusan KPI berikutnya, termasuk dalam hal perpanjangan izin lembaga penyiaran yang bersangkutan.

2. Bila KPI menemukan bahwa terjadi pelanggaran oleh lembaga penyiaran, KPI akan mengumumkan pelanggaran itu kepada publik, sementara lembaga penyiaran bersangkutan wajib mengumumkan pula keputusan tersebut melalui siarannya. ${ }^{6}$

KPID dalam memahami ketentuan perundang-undangan tersebut dan memedomaninya kemudian dalam istilah Pre Undestanding Gadamer disebut dengan istilah Vorhabe. Istilah Vorhabe sendiri dipahami sebagai upaya yang dilakukan seseorang dalam proses memahami, dimana dalam proses memahami seseorang senantiasa memiliki pemahaman awal tentang apa yang akan dipahaminya Dalam konteks artikel ini, KPID dalam menjalankan tugas dan fungsinya sebagai lembaga independent sebelum dan sesudah melakukan pengawasan kepada lembaga penyiaran mengacu pada UU 32 dan P3SPS, sehingga Pre Uderstanding / Vorhabe KPID adalah memahami UU No 32 dan P3SPS.

\section{Effective Histori KPID NTB Terhadap Undang-Undang Penyiaran No. 32 Tahun 2002 Dan P3SPS Dalam Melakukan Pengawasan Siaran.}

Menurut Gadamer, selama masih menjadi manusia normal pasti ada Pre Understanding, yaitu selama manusia masih bisa mikir pasti terlibat Pra-Pemahaman, ketika pikiran itu mandeg, maka pasti saat itu juga manusia tidak menggunakan Pre Understanding, atau kita tidak bisa mikir tentang apa saja. Dari beberapa penjelasan tersebut kemudian Gadamer memunculkan sebuah teori yang cukup phenomenal yang disebut dengan Effective History (Sejarah Pengaruh).

Gadamer menjelaskan bahwa selalu ada "sejarah pengaruh" yang berkerja dalam aktifitas memahami. "Sejarah pengaruh" membuktikan bahwa setiap orang "berada dalam sejarah" tidak pernah "keluar dari sejarah" olehkarena itu tidak mungkin ada orang yang bisa melakukan pemahaman / refleksi dengan cara "keluar dari realitas sejarah". Begitu juga dalam konteks pemahaman KPID terhadap tugas dan fungsinya yang memedomani UU No 32 dan P3SPS tentang penyiaran yang tidak akan mampu kelur dari zona kesejarahan yang melingkupinya.

Oleh karena itu, dalam merumuskan regulasi dan menerapkannya di tengah masyarakat, tentunya regulasi tersebut tidak akan bertentangan dengan budaya masyarakat dan public

6 . Rachmat Kriyantono, Pemberdayaan Konsumen Televisi Melalui Keterampilan Medialiteracy dan Penegakan Regulasi Penyiaran.Jurnal Ilmu Komunikasi, Vol 10 No 21, ISSN 1978-5518 
lembaga penyiaran. Artinya bahwa regulasi tersebut dibentuk berdasarkan bagaimana sejarah dan budaya yang pernah ada di Indonesia dan dikembangkan oleh generasi berikutnya.

Adanya regulasi yang mengatur dan menjamin public untuk mendapatkan informasi setidaknya mampu memberikan edukasi bagi masyarakat, karena jika mengacu pada definisi informasi merupakan "proses pengolahan data dalam suatu bentuk yang lebih berguna dan lebih berarti bagi penerimanya yang menggambarkan suatu kejadian-kejadian yang nyata yang digunakan untuk pengambilan keputusan".7

Pemaknaan tentang informasi yang demikian kemuadian melahirkan kategorisasi terhadap informasi tersebut, dimana menurut para ahli, bahwa jenis informasi terdiri atas bermacam-macam bentuk, yakni berupa berita, hiburan dan ilmu pengetahuan. Landasan dari fungsi pelayanan informasi yang sehat adalah seperti yang tertuang dalam Undangundang Penyiaran Nomor 32 Tahun 2002 yaitu Diversity of Content (prinsip keberagaman isi) dan Diversity of Ownership (prinsip keberagaman kepemilikan). ${ }^{8}$

Kedua prinsip tersebut menjadi landasan bagi setiap kebijakan yang dirumuskan oleh Komisi Penyiaran Indonesia (KPI). Pelayanan informasi yang sehat berdasarkan Diversity of Content (prinsip keberagaman isi) adalah tersedianya informasi yang beragam bagi publik baik berdasarkan jenis program maupun isi program. Sedangkan Diversity of Ownership (prinsip keberagaman kepemilikan) adalah jaminan bahwa kepemilikan media massa yang ada di Indonesia tidak terpusat dan dimonopoli oleh segelintir orang atau lembaga saja. Prinsip Diversity of Ownership juga menjamin iklim persaingan yang sehat antara pengelola media massa dalam dunia penyiaran.

Regulasi tentang layanan informasi yang sehat dan edukatif bagi masyarakat sebagaimana yang telah dijelaskan sebelumnya telah diatur dengan cukup jelas, baik tentang proses perizinan, konten siaran hingga pemberian sanksi bagi lembaga-lembaga penyiaran yang melanggar regulasi tersebut.

Dari beberapa hasil survei media oleh KPID NTB yang melibatkan 800 pelajar SMA di kota Mataram pada Januari hingga Februari 2015 terungkap 64 persen responden merupakan penggemar siaran TV, 18 persen mendengarkan siaran radio dan 13 persen mengaku menyukai "chatting" internet. Hasil survey tersebut menunjukkan bahwa penetrasi siaran TV lebih tinggi dibandingkan media lainnya, namun menurut survei juga

7 . Gordon B. Davis, Kerangka Dasar Sistem Informasi Manajemen Bagian 1, (Jakarta: PT Pustaka Binamas Pressindo, 1991), hlm.12

8. UU RI No 32 Th. 2002 dan Peraturan Menkominfo Th. 2007 Tentang Penyiaran dan UU RI No. 40 Th. 1999 Tentang Pers - R708 
menunjukkan porno aksi adalah tayangan TV yang paling dikeluhkan responden yakni mencapai 54 persen, sedangkan tayangan kekerasan 22 persen.

Hasil survei lainnya yang dilakukan KPID NTB juga menunjukkan bahwa ada kecenderungan pelajar menyukai tayangan sinetron dan film yang mencapai 64 persen, siaran berita 15 persen dan reality show 12 persen, sementara siaran radio yang paling digemari adalah permintaan (request) lagu yang mencapai 76 persen.

Dari beberapa informasi hasil survey tersebut menegaskan bahwa harus diakui siaran TV mempunyai pengaruh kuat terhadap khalayaknya, pengaruh TV tidak hanya pada tataran kognitif (kesadaran dan pengetahuan), tetapi juga sampai ke tataran afektif (sikap) dan kognatif (perilaku).

Apabila jumlah lembaga penyiaran sebelumnya baik radio maupun Tv jumlahnya tidak terlalu banyak, maka saat ini jumlahnya mencapai ratusan buah, bahkan KPID NTB mencatat ada sedikitnya 135 lembaga penyiaran yang terdaftar dan aktif bersiaran tersebar muai dari Ampenan Mataram hingga Sape Bima. Keberadaan lembaga penyiaran yang sedemikian banyak tersebut tentu saja akan membawa dampak positif dan negatif, dari sisi positif setidaknya, memberi banyak pilihan bagi masyarakat untuk memperoleh sumber informasi dan hiburan.

Jika menggunakan perspektif UU No. 322002 dan P3SPS dalam kontek dunia penyiaran, maka bisa dikatakan ada beberapa permasalahan pelanggaran pedoman UU 32 dan P3SPS tentang penyiaranan baik radio dan Tv yang ada di NTB. Lembaga penyiaran lokal baik radio maupun $T_{v}$ belum sepenuhnya mengacu pada regulasi penyiaran dan memberikan jaminan kepada public tentang kualitas informasi yang mereka terima, khususnya anak-anak dan remaja.

Fakta di lapangan menunjukkan bahwa KPID Provinsi NTB mencoba merealisasikan komitmen mereka untuk menjamin masyarakat mendapatkan informasi yang berkualitas, maka KPID menerima pengaduan warga terkait siaran radio dan atau tayangan televisi yang dinilai tidak mendidik. Pengaduan yang berisi nama lembaga penyiaran (radio/TV), nama acara, jam siar dan uraian keberatan/kritik dapat dikirim melalui SMS ke nomor 0818544386, 081353598051, serta melalui surat yang dialamatkan ke Bidang Pengawasan Isi Siaran KPID NTB Jalan Udayana 14 Mataram, Lombok, NTB.

Pelanggaran UU 32 dan P3SPS oleh lembaga penyiaran lokal, dari fakta lapangan menunjukkan bahwa sanksi yang diberikan oleh KPID masih sebatas teguran saja meskipun sudah sesuai dengan pasal 15 tentang setiap orang yang melanggarketentuan sebagaimana 
dimaksud dalam Pasal 15 ayat (2),Pasal 20, Pasal 23, Pasal 24, Pasal 26 ayat (2),Pasal 27, Pasal 28, Pasal 33 ayat (7),Pasal 34 ayat (5)huruf a, huruf c,huruf d, dan huruf f, Pasal 36 ayat (2), ayat (3), dan ayat (4), Pasal 39 ayat (1), Pasal 43 ayat (2), Pasal 44 ayat (1), Pasal 45 ayat (1), Pasal 46 ayat (6), ayat (7), ayat (8), ayat (9), dan ayat (11), dikenai sanksi administratif. (2) Sanksi administrative sebagaimana dimaksud dalamayat (1) dapat berupa :

a. teguran tertulis;

b. penghentian sementara mata acara yang bermasalah setelah melalui tahap tertentu;

c. pembatasan durasi dan waktu siaran;

d. denda administratif;

e. pembekuan kegiatan siaran untukwaktu tertentu;

f. tidakdiberi perpanjangan izin penyelenggaraan penyiaran;

g. pencabutan izin penyelenggaraan penyiaran,

Ketentuan mengenai sanksi dalam pasal dan ayat tersebut maksimal yang diberlakukan dalam konteks lembaga penyiaran local yang ada di wilayah KPID NTB adalah memberikan sanksi paling tegas adalah mencabut izin siaran untuk beberapa saat saja, setelah itu KPID akan memberikan izin siaran kembali kepada lembaga penyiaran setelah melalui proses pengawan dan pemantauan. Proses pengawasan dan pemantauan yang dilakukan oleh KPID NTB terhadap lembaga penyiaran local pada prinsipnya telah mengikuti Standard Operasional Prosedur (SOP). Artinya antara apa yang menjadi tugas dan fungsi KPID NTB yang tertera pada regulasi ataupun perundang-undangan telah sesuai, sehingga dengan mengacunya pada pelaksanaan tugas dan fungsi tersebut, maka seperti itulah gambaran awal tentang pemahaman tugas dan fungsi mereka jika melihatnya menggunakan istilah hermeneutika Effective Histori Gadamer.

\section{Fusion Of Horisons KPID NTB Terhadap Undang-Undang Penyiaran No. 32 Tahun 2002 Dan P3SPS Dalam Melakukan Pengawasan Siaran.}

Menurut Gaddamer, horison dapat diartikan sebagai perspektif, pengetahuan atau kesadaran. Fusion of Horisons berarti meleburnya Horison yang memahami dengan yang dipahami dan melahirkan horison yang baru. Peleburan ini pada ahirnya akan menjadikan horison yang dimiliki oleh seorang pemaham akan semakin luas. Misalnya bagaimana membaca buku komik waktu kecil dulu dengan saat dewasa sekarang akan sangat berbeda 
karena horison yang dimiliki sewaktu kecil dan dewasa semakin luas. Oleh karena itu interpretasi yang berhasil itu coraknya bukan Reproduksi Makna lama namun Produksi Makna karena hasil interperetasi selalu horison-horison yang baru. ${ }^{9}$ Begitu juga dalam pemahaman penulis tentang bagaimana pemahaman KPID Terhadap Undang-Undang Penyiaran No. 32 Tahun 2002 Dan P3SPS Dalam Melakukan Pengawasan Siaran yang pastinya mengalami Fusion of Horisons.

Komisi Penyiaran Indonesia Daerah / KPID NTB berdasarkan pada UU 32 Tahun 2002 diberi kewenangan untuk mengatur dan menciptakan regulasi dalam bidang penyiaran. Melalui kewenangan tersebut KPI/KPID mewujudkan regulasi penyiaran dalam bentuk P3SPS (Pedoman Perilaku Penyiaran dan Standar Program Siaran). P3SPS disusun berdasarkan masukan dari kalangan masyarakat, akademisi, ormas dan juga praktisi penyiaran. Melalui P3SPS diharapkan dapat menjadi dasar bagi lembaga penyiaran dalam menyajikan program siaran yang berkualitas, sehat, dan bermartabat.

Tujuan dari pedoman perilaku penyiaran dijelaskan dalam pasal 4 Peraturan KPI tentang Pedoman Perilaku Penyiaran Pedoman Perilaku Penyiaran memberi arah dan tujuan agar lembaga penyiaran:

a. Menjunjung tinggi dan meningkatkan rasa persatuan dan kesatuan Negara Kesatuan Republik Indonesia;

b. Meningkatkan kesadaran dan ketaatan terhadap hokum dan segenap peraturan perundang-undangan yang berlaku di Indonesia.

c. Menghormati dan menjunjung tinggi norma dan nilai agama dan budaya bangsa yang multicultural.

d. Menghormati dan menjunjung tinggi etika profesi yang diakui peraturan perundangundangan.

e. Menghormati dan menjunjung tinggi prinsip-prinsip demokrasi.

f. Menghormati dan menjunjung tinggi hak asasi manusia.

g. Menghormati dan menjunjung tinggi hak dan kepentingan publik

h. Menghormati dan menjunjung tinggi hak anak-anak dan remaja.

i. Menghormati dan menjunjung tinggi hak orang atau kelompok masyarakat tertentu.

j. Menjunjung tinggi prinsip-prinsip jurnalistik.

${ }^{9}$. Hans Georg Gadamer, Truth and Method Hans Georg Gadamer, translations revised by Joel Weinsheimer and Donald G Marshal (Newyork: Continuum Publishing Group, 2004), hlm. 11-23 


\section{Pasal-Pasal P3SPS KPI Yang Dilanggar Oleh Lembaga Penyiaran Lokal Menurut KPID NTB}

a. Pasal 24 : Lembaga penyiaran dilarang menyiarkan secara langsung penjarahan serta tindakan-tindakan merusak oleh massa yang dapat menimbulkan kepanikan atau mendorong masyarakat di daerah lain meniru perilaku tersebut.

b. Pasal 32 : Program atau promo program yang mengandung muatan kekerasan secara dominan, atau mengandung adegan kekerasan eksplisit dan vulgar, hanya dapat disiarkan pada jam tayang dimana anak-anak pada umumnya diperkirakan sudah tidak menonton televisi, yakni pukul 02.00-03.00 sesuai dengan waktu stasiun penyiaran yang menayangkan.

c. Pasal 44 : Lembaga penyiaran dilarang menyiarkan adegan tarian dan atau lirik yang dapat dikategorikan sensual, menonjolkan seks, membangkitkan hasrat seksual, atau memberi kesan hubungan seks.

d. Pasal 46 : Program yang berisikan pembicaraan atau pembahasan mengenai masalah seks harus disajikan dengan cara ilmiah dan santundan tidak menjadi ajang pembicaraan mesum.

e. Pasal 57 ayat 1 : Program faktual yang bertemakan gaib, paranormal, klenik, praktik spiritual, magis, mistik, kontak dengan roh, hanya dapat disiarkan pukul 22.00-03.00 sesuai dengan waktu stasiun menayangkan.

\section{Beberapa Program Siaran Lembaga Penyiaran Lokal Yang Di Tegur KPID NTB}

Dalam Kurun Waktu Setahun, KPID NTB Temukan 3.700 Temuan Pelanggaran Siaran Televisi Maupun Radio. Komisi Penyiaran Daerah (KPID) NTB mengintensifkan pemantauan isi siaran lembaga penyiaran baik radio maupun televisi melalui pusat monitoring siaran. Pada proses monitoring yang dilakukan oleh komisioner KPID NTB, terdapat beberapa hasil monitoring terhadap lembaga penyiaran baik radio maupun $\mathrm{T}_{\mathrm{v}}$, dimana sekitar 3.788 temuan pelanggaran konten siaran, terutama selama kurun waktu 2014-2018.

Permasalahan pelanggaran penyiaran yang dilakukan oleh lembaga penyiaran tersebut secara garis besar masuk dalam kategori pelanggaran yang berhubungan dengan klasifikasi isi siaran dan hak cipta, siaran pemilu, penyiaran atau penayangan lagu dengan lirik tidak pantas atau lirik porno, video klip yang erotis, adegan kekerasan pada siaran iklan dan program siaran jurnalistik. 
Tindak lanjut dari temuan KPID tersebut kemudian melahirkan beberapa kebijakan yang dikeluarkan oleh KPID. Beberapa kebijakan dan tindakan yang dimaksud diantaranya dengan memberikan sanksi kepada lembaga penyelenggara siaran, mulai dari teguran, pemanggilan, klarifikasi hingga penghetian sementara tayangan program yang bermasalah. Data-data di lapangan menunjukkan keseriusan dan komitmen KPID NTB dalam hal menerapkan P3SPS sebagai pedoman dalam menentukan standar siaran, dimana bukti keseriusan tersebut diantaranya adalah:

Pertama, KPID telah menghentikan sementara program tayangan wayang kulit Lalu Nasib yang disiarkan di stasiun Lombok Tv. Pemberhentian penayangan program siaran tersebut dengan alasan bahwa penggunaan bahasa yang kasar, kotor, mendiskreditkan kelompok-kelompok tertentu. Kategori siaran tersebut merupakan pelanggaran terhadap pasal 24 ayat (1) Standar Program Siaran yang melarang program siaran menampilkan ungkapan kasar dan makian, baik secara verbal maupun nonverbal, yang mempunyai kecenderungan menghina atau merendahkan martabat manusia, dan kemudian program ini diberhentikan dan tidak boleh ditayangkan lagi.

Kedua, (KPID) program Lejel Home Shopping yang sudah lama tayang di Lombok TV. Program ini menurut KPID NTB, merupakan program blocking time tentang promosi berbagai macam produk perusahaan.Namun dalam sejumlah episode, mempromosikan produk pakaian dalam wanita (korset) yang menampilkan visualisasi bagian-bagian tubuh tertentu secara jelas dan vulgar, ditayangkan ketika anak-anak dan remaja masih menonton. "Program ini juga kita minta dievaluasi durasinya karena kerapkali melampaui ketentuan iklan komersial di lembaga penyiaran swasta maksimal 20\% dari total jam siar sehari," tegasnya.

Program siaran tersebut sudah menyalahai P3SPS pasal Pasal 32 : yang menjelaskan bahwa program atau promo program yang mengandung muatan kekerasan secara dominan, atau mengandung adegan kekerasan eksplisit dan vulgar, hanya dapat disiarkan pada jam tayang dimana anak-anak pada umumnya diperkirakan sudah tidak menonton televisi, yakni pukul 02.00-03.00 sesuai dengan waktu stasiun penyiaran yang menayangkan. Kemudian Pasal 44 : Lembaga penyiaran dilarang menyiarkan adegan tarian dan atau lirik yang dapat dikategorikan sensual, menonjolkan seks, membangkitkan hasrat seksual, atau memberi kesan hubungan seks. 
Ketiga, Lintas Musik Nasional dan Hang out di TV9 Lombok dihentikan sementara karena mengabaikan kewajiban mencantumkan hak siar. "Aturannya sangat jelas mewajibkan setiap lembaga penyiaran mencantumkan keterangan informasi seputar judul lagu, nama pencipta lagu, penyanyi termasuk bila menggunakan potongan gambar, video dan audio harus disebutkan sumbernya karena menyangkut hak siar,” Penghentian sementara program film kartun Kastari Animation di Sasambo TV karena mengabaikan penggolongan klasifikasi acara yang tidak sesuai dengan target khalayak dan keliru menempatkan posisi atau letak klasifikasi acara yang seharusnya di sudut atas.layar televisi. Penghentian program siaran tersebut dikarenakan melanggar P3SPS pasal 34 yang mengatakan bahwa lembaga penyiaran dalam menyiarkan program siaran wajib memiliki dan mencantumkan hak siar. Kedua kepemilikan hak siar sebagaimana dimaksud dalam ayat (1) harus disebutkan secara jelas dalam setiap program siaran.

Keempat, KPID NTB menghentikan program acara faktual Sasambo TV yakni Mata Indonesia, Lintas Nusantara dan Titian Imani. "Pelanggarannya sama saja dengan program Kastari Animation, sesuatu yang mereka anggap sepele padahal itu prinsip dan normatif," penghentian program siaran tersebut karena dianggap melanggar P3SPS pasal Pasal 57 ayat 1 : Program faktual yang bertemakan gaib, paranormal, klenik, praktik spiritual, magis, mistik, kontak dengan roh, hanya dapat disiarkan pukul 22.00-03.00 sesuai dengan waktu stasiun menayangkan.

Beberapa lembaga penyiaran beserta program siaran yang disampaikan di atas hanyalah sebagian kacil dari apa yang menjadi contoh pelanggaran P3SPS, sehingga lembaga penyiaran beserta program siaran tersebut ahrus diberikan sanksi oleh KPID NTB. Konsekuensi yang diberikan oleh KPID kepada lembaga penyiaran tersebut adalah, selama menjalankan sanksi penghentian sementara, ketiga stasiun TV tersebut tidak diperkenankan menyiarkan program dengan format sejenis atau pada waktu siar yang sama atau waktu yang lain.

Jika melihat tugas KPID dalam menjalankan fungsinya dengan menggunakan teori implementasi kebijakan publik dapat dilihat dari beberapa perspektif atau pendekatan. Salah satunya ialah implementation problems approach yang diperkenalkan oleh Edwards III. ${ }^{10}$ Edwards III mengajukan pendekatan masalah implementasi dengan terlebih dahulu mengemukakan dua pertanyaan pokok, yakni:

${ }^{10}$. Edward III, George C (edited), Public Policy Implementing, (London-England: Jai Press Inc, 1984), hlm. 9-10 
a. Faktor apa yang mendukung keberhasilan implementasi kebijakan, dalam hal ini kebijakan implementasi Undang-Undang Penyiaran No 32 dan Pedoman Perilaku Penyiaran dan Penetapan Standar Siaran (P3SPS) ?

b. Faktor apa yang menghambat keberhasilan implementasi kebijakan, dalam hal ini kebijakan implementasi Undang-Undang Penyiaran No 32 dan Pedoman Perilaku Penyiaran dan Penetapan Standar Siaran (P3SPS)?

Berdasarkan kedua pertanyaan tersebut dirumuskan empat faktor yang merupakan syarat utama keberhasilan proses implementasi, yakni komunikasi termasuk sosialisasi Undang-Undang Penyiaran No 32 dan Pedoman Perilaku Penyiaran dan Penetapan Standar Siaran (P3SPS) kepada semua lembaga penyiaran, sumber daya, sikap birokrasi atau pelaksana dan struktur organisasi (ketegasan, komitmen dalam penegakkan Undang-Undang Penyiaran No 32 dan Pedoman Perilaku Penyiaran dan Penetapan Standar Siaran (P3SPS), termasuk tata aliran kerja birokrasi. Empat faktor tersebut menjadi kriteria penting dalam implementasi suatu kebijakan.

Jika melihat apa yang selama ini dilakukan oleh KPID dalam menjalankan tugas dan fungsinya sebagai sebuah lembaga yang berkewajiaban untuk melakukan pengasan terhadap lembaga penyiaran, terutama mengacu pada empat syarat pengelolaan desiminasi kebijakan sebagai berikut:

a. Adanya respek anggota masyarakat terhadap otoritas pemerintah untuk menjelaskan perlunya secara moral mematuhi undang-undang yang dibuat oleh pihak berwenang. Lembaga penyiaran yang ada belum bisa dikatakan telah merspon tentang perlunya secara moral untuk mematuhi Undang-Undang Penyiaran No 32 dan Pedoman Perilaku Penyiaran serta Penetapan Standar Siaran (P3SPS). Hal ini ditunjukkan dengan ditemukannya pelanggaranpelanggaran terhadap ketentuan standar siaran yang berlaku, seperti kualifikasi umur dalam program siaran, penggunaan bahasa dan budaya luar sebagai bahasa siaran. Meskipun proses sosialisasi Undang-Undang Penyiaran No 32 dan Pedoman Perilaku Penyiaran serta Penetapan Standar Siaran (P3SPS) sudah dilakukan dan lembaga penyiaran memahami tentang regulasi tersebut, bahkan sanksi-sanksipun sudah diberikan, namun tetap saja masih diberlakukan. 
b. Adanya kesadaran untuk menerima kebijakan. Kesadaran dan kemauan menerima dan melaksanakan kebijakan terwujud manakala kebijakan dianggap logis. Indicator adanya kesadaran untuk menerima kebijakan dan kemauan untuk menerima dan melaksanakan kebijakan oleh lembaga penyiaran local yang ada di NTB secara formalitas sudah dilaksanakan, namun cukup disayangkan ketika sikap tersebut hanya berhenti sampai pada tataran formalitas saja (proses pengurusan izin untuk siaran).

c. Keyakinan bahwa kebijakan dibuat secara sah. Tingkat kesadaran lembaga penyiaran terhadap keyakinan bahwa kebijakan dibuat secara sah secara umum sudah cukup baik, hal ini dibuktikan dengan kelengkapan bahan dan persyaratan dalam proses perizinan untuk mendapatkan izin siaran hampir terpenuhi semua, namun cukup disayangkan karena hal-hal tersebut hanya berlaku pada tataran formalitas belaka, tidak diimplementasikan dalam proses siaran.

d. Awalnya suatu kebijakan dianggap kontroversial, namun dengan berjalannya waktu maka kebijakan tersebut dianggap sebagai sesuatu yang wajar.

Jika menggunakan pendekatan atau teori lainnya untuk menguji bagaimana implemntasi Undang-Undang penyiaran no 32 dan Pedoman Perilaku Penyiaran serta Penetapan Standar Siaran (P3SPS), Ripley menawarkan satu konsep yang disebut dengan pendekatan "kepatuhan" dan pendekatan "faktual” dalam implementasi kabijakan. ${ }^{11}$

Pendekatan "kepatuhan" memusatkan perhatian pada tingkat kepatuhan agen atau individu bawahan terhadap agen atau individu atasan (semua komisioner KPID dan lembaga penyiaran berjibaku untuk mensosialisasikan dan mengimplemntasikan Undang-Undang penyiaran No 32 dan Pedoman Perilaku Penyiaran serta Penetapan Standar Siaran/P3SPS). Jika mengacu pada konsep kepatuhan yang disampaikan oleh Ripley tersebut untuk melihat implementasi Undang-Undang penyiaran No 32 dan Pedoman Perilaku Penyiaran serta Penetapan Standar Siaran (P3SPS) maka terdapat permasalahan yang cukup serius. Permasalahan yang peneliti maksudkan adalah adanya sikap ketidakpatuhan yang dipraktikkan oleh sebagian besar lembaga penyiaran

11 . Ripley, Rendal B. and Grace A. Franklin. Policy Implementation and Bureaucracy, second edition, (ChicagoIllionis: the Dorsey Press,1986), hlm 11 
yang ada, terbukti dengan masih detemukannya beberapa jenis pelanggaran dalam penetapan standar siaran atau bahkan melanggar Undang-Undang Penyiaran No 32.

Menrut pengamatan peneliti bahwa ditemukan factor lain yang menyebabkan terjadinya ketidakpatuhan tersebut, dimana tahapan pengawsan dilakukan sesuai prosedur, namun hanya pada dataran formalitas. Menurut hermeneutika Gaddamer, apapun yang dikembangkan dalam konteks pemikiran termasuk hukum tidak muncul dengan sendirinya, tetapi selalu mengacu pada konsep lama yang telah dikembangkan oleh generasi sebelumnya. Konsep pengembangan tersebut kemudian disebut dengan tradisi dan otoritas. Dua istilah tersebut kemudian dijadikan sebagai pijakan awal dalam proses memahami hukum, yaitu pemahaman KPID terhadap UU No 32 dan P3SPS tentang penyiaran.

Gadamer dengan teori Effective History menjelaskan bahwa selalu ada "sejarah pengaruh” yang berkerja dalam aktifitas memahami. Begitu juga dalam konteks pemahaman KPID terhadap tugas dan fungsinya yang memedomani UU No 32 dan P3SPS tentang penyiaran yang tidak akan mampu kelur dari zona kesejarahan yang melingkupinya.

Menurut Gaddamer Fusion of Horisons berarti meleburnya Horison yang memahami dengan yang dipahami dan melahirkan horison yang baru. Oleh karena itu interpretasi yang berhasil itu coraknya bukan Reproduksi Makna lama namun Produksi Makna karena hasil interperetasi selalu horison-horison yang baru. ${ }^{12}$ Begitu juga dalam pemahaman penulis tentang bagaimana pemahaman KPID Terhadap Undang-Undang Penyiaran No. 32 Tahun 2002 Dan P3SPS Dalam Melakukan Pengawasan Siaran yang pastinya mengalami Fusion of Horisons, interpretasi yang berhasil itu coraknya bukan Reproduksi Makna lama namun Produksi Makna karena hasil interperetasi selalu horison-horison yang baru. Sehingga KPID NTB dalam mewujudkan visi dan misi pengawasan dan penetapan standar siaran berdasarkan UU 32 tentang penyiaran merealisasikannya dengan baik meskipun masih dalam dataran formalitas, sehingga yang dibutuhkan oleh KPID NTB jika ingin memaksimalkan tugas dan fungsinya adalah menafsirkan kembali regulasi tersebut dalam bentuk kebijakan yang lebih kreatif dan inovatif berdasarkan karakteristik budaya masyarakat NTB sebagaimana beberapa teori hermeneutika Gaddamer.

12 . Hans Georg Gadamer, Truth and Method Hans Georg Gadamer, translations revised by Joel Weinsheimer and Donald G Marshal (Newyork: Continuum Publishing Group, 2004), hlm. 11-230 


\section{Penutup}

Pelaksanaan tugas KPID sebagai lembaga yang otoritatif dalam melakukan pengawasan masih dalam datran formalitas procedural dalam menjalankan amanah UU No 32 dan P3SPS tentang penyiaran. Meski tahapan pengawasan dilakukan sesuai prosedur, namun kebijakan tersebut disayangkan hanya berlaku pada dataran formalitas. Dalam logika hermeneutika Gaddamer, apapun yang dikembangkan dalam konteks pemikiran termasuk hukum tidak muncul dengan sendirinya, tetapi selalu mengacu pada konsep lama yang telah dikembangkan oleh generasi sebelumnya. Konsep pengembangan tersebut kemudian disebut dengan tradisi dan otoritas. Dua istilah tersebut kemudian dijadikan sebagai pijakan awal untuk melakukan pengembangan berikutnya, termasuk dalam pengembangan dalam proses memahami hokum, terutama dalam konteks pemahaman KPID terhadap UU No 32 dan P3SPS tentang penyiaran.

Gadamer dengan teori Effective History menjelaskan bahwa selalu ada "sejarah pengaruh" yang berkerja dalam aktifitas memahami. "Sejarah pengaruh" membuktikan bahwa setiap orang "berada dalam sejarah" tidak pernah "keluar dari sejarah" karena itu tidak mungkin ada orang yang bisa melakukan pemahaman / refleksi dengan cara "keluar dari realitas sejarah”. Begitu juga dalam konteks pemahaman KPID terhadap tugas dan fungsinya yang memedomani UU No 32 dan P3SPS tentang penyiaran yang tidak akan mampu kelur dari zona kesejarahan yang melingkupinya.

Menurut Gaddamer Fusion of Horisons berarti meleburnya Horison yang memahami dengan yang dipahami dan melahirkan horison yang baru. Oleh karena itu interpretasi yang berhasil itu coraknya bukan Reproduksi Makna lama namun Produksi Makna karena hasil interperetasi selalu horison-horison yang baru. ${ }^{13}$

Dengan demikian, KPID NTB dalam mewujudkan visi dan misi pengawasan dan penetapan standar siaran berdasarkan UU 32 tentang penyiaran merealisasikannya dengan baik meskipun masih dalam dataran formalitas, sehingga yang dibutuhkan oleh KPID NTB jika ingin memaksimalkan tugas dan fungsinya adalah menafsirkan kembali regulasi tersebut dalam bentuk kebijakan yang lebih kreatif dan inovatif berdasarkan karakteristik budaya masyarakat NTB sebagaimana beberapa teori hermeneutika Gaddamer.

13. Hans Georg Gadamer, Truth and Method Hans Georg Gadamer, translations revised by Joel Weinsheimer and Donald G Marshal (Newyork: Continuum Publishing Group, 2004), hlm. 11-23 


\section{Daftar Pustaka}

B. Davis, Gordon, Kerangka Dasar Sistem Informasi Manajemen Bagian 1. Jakarta: PT Pustaka Binamas Pressindo, 1991

Edward III, George C (edited), Public Policy Implementing. London-England: Jai Press Inc, 1984

Eko, Prasetyo, Febri, Peranan Komunikasi Dalam Mengoptimalkan Komisi Penyiaran Indonesia Daerah (KPID) Kalimantan Timur Dalam Melakukan Pengawasan Lembaga Penyiaran di Samarinda e-Jurnal Ilmu Komunikasi, 2015 FISIP-UNMUL

Georg, Gadamer Hans, Truth and Method Hans Georg Gadamer, translations revised by Joel Weinsheimer and Donald G Marshal. Newyork: Continuum Publishing Group, 2004

Kriyantono, Rachmat, Pemberdayaan Konsumen Televisi Melalui Keterampilan Medialiteracy dan Penegakan Regulasi Penyiaran.Jurnal Ilmu Komunikasi, Vol 10 No 21, ISSN 1978-5518

Rendal, B Ripley. Grace A. Franklin. Policy Implementation and Bureaucracy, second edition. Chicago-Illionis: the Dorsey Press,1986

Sunario, Astrid, Komunikasi Pengendalian dan Komunikasi Pengawasan. Jakarta : Pustaka Sinar Harapan, 1989

UU RI No 32 Th. 2002 dan Peraturan Menkominfo Th. 2007 Tentang Penyiaran dan UU RI No. 40 Th. 1999 Tentang Pers - R708 